\title{
Effects of Light Exposure, Bottle Colour and Storage Temperature on the Quality of Malvasia delle Lipari Sweet Wine
}

\author{
Elena Arena ${ }^{1}$, Valeria Rizzo ${ }^{1, *(D)}$, Fabio Licciardello ${ }^{2}\left(\mathbb{D}\right.$, Biagio Fallico $^{1}$ and Giuseppe Muratore ${ }^{1(D)}$ \\ 1 Department of Agriculture, Food and Environment (Di3A), University of Catania, Via Santa Sofia, 100, \\ 95123 Catania, Italy; elena.arena@unict.it (E.A.); biagio.fallico@unict.it (B.F.); g.muratore@unict.it (G.M.) \\ 2 Department of Life Sciences, University of Modena and Reggio Emilia, Via Amendola 2, \\ 42122 Reggio Emilia, Italy; fabio.licciardello@unimore.it \\ * Correspondence: vrizzo@unict.it
}

Citation: Arena, E.; Rizzo, V.; Licciardello, F.; Fallico, B.; Muratore, G. Effects of Light Exposure, Bottle Colour and Storage Temperature on the Quality of Malvasia delle Lipari Sweet Wine. Foods 2021, 10, 1881. https://doi.org/10.3390/foods 10081881

Academic Editor: Maurizio Cian

Received: 20 June 2021

Accepted: 12 August 2021

Published: 14 August 2021

Publisher's Note: MDPI stays neutral with regard to jurisdictional claims in published maps and institutional affiliations.

Copyright: (C) 2021 by the authors Licensee MDPI, Basel, Switzerland. This article is an open access article distributed under the terms and conditions of the Creative Commons Attribution (CC BY) license (https:// creativecommons.org/licenses/by/ $4.0 /)$.

\begin{abstract}
The influence of light exposure, bottle color and storage temperature on the quality parameters of Malvasia delle Lipari (MdL) sweet wine were investigated. Wine samples bottled in clear-colored (colorless, green and amber) glass were stored under different artificial lighting conditions, in order to simulate the retail environment (one cool-white, fluorescent lamp) and to perform an accelerated test (four and six cool-white, fluorescent lamps). The storage temperature was kept constant $\left(25^{\circ} \mathrm{C}\right)$ for the first 90 days of the experiment and then samples were monitored for up to 180 days at higher temperatures $\left(30,35\right.$ and $\left.40^{\circ} \mathrm{C}\right)$. The principal enological parameters, total phenols, color, 5-hydroxymethylfurfural (HMF) and 2-furaldehyde (2F) contents were studied. The shelf-life test pointed out minimum variations of the basic chemical parameters, while the quality attributes most affected by lighting were color, together with HMF and $2 \mathrm{~F}$ levels which, hence, can be considered as indicators of the severity of storage conditions.
\end{abstract}

Keywords: Malvasia; sweet wine; shelf-life; accelerated shelf-life test; 5-hydroxymethylfurfural; 2-furaldehyde

\section{Introduction}

The primary objective of packaging is to protect and retain, as much as possible, the quality of foods and beverages. The classical packaging material for wine is glass, appreciated primarily for its oxygen barrier [1], clarity and inertness: this feature, with respect to the migration of low molecular weight compounds from the package to the product and/or flavor scalping by the packaging material is of the utmost importance [2,3]. Wine has traditionally been stored in glass bottles of different colors and shapes, whose selection is often driven from market forces in the attempt to make the wine readily identifiable and more attractive to the consumer.

Wine shelf-life is defined as the time that it remains stable, in terms of its chemistry, microbiology and biochemistry as well as its sensory properties [4], however chemical changes may occur during storage, improving some quality parameters. Color is among the main sensory attributes determining consumers' preference and it is considered a major feature for the assessment of red wine quality [5]. The color of white wines tends to brown after bottling [6], due to the effect of oxidation of the phenolic compound and to enzymatic reactions $[7,8]$. Thus, during storage and ageing, the chemical composition of wine is subjected to continuous changes, which may be desired or not, depending on the type of wine. Phenolics and volatile compounds as well as color and nutrients could be influenced by the lighting and temperature of the retail shops, and the optimization of packaging variables could contribute to wine quality preservation, from production to consumption.

Many authors have studied the effects of time, temperature and storage conditions on the phenolics composition and color of red wines [9-11]. A significant decrease of phenolics 
content and a change in the color of the white wine from pale yellow to yellow brown during storage, was reported. Time of storage seems to influence the color parameters and the total phenols content more with respect to temperature and light exposure [12]. Other authors [13] did not find color change, and total phenols decreased up to nine months of storage of Hellenic varietal white wine.

The deteriorative effect of light depends on other factors, such as the duration of light exposure, light spectra and intensity and the composition of the food product. It is well known that the exposure of some foods to ultraviolet radiation and visible light accelerates oxidative deterioration. In alcoholic beverages, the aroma, flavor and color easily deteriorate for light-induced oxidative processes. The effect of light can be explained by both photolytic autoxidation, which corresponds to the production of radicals during exposure to UV light, and photosensitized oxidation, that occurs in the presence of photosensitizers and ultraviolet or visible light. The roles of light, temperature and, more frequently, also the color of the glass bottle in white wine, have been extensively analyzed in order to evaluate their impact on light-induced oxidative degradation, changes on pigment, phenolic compounds, and mainly on enological parameters [14-18]. Clark et al. [19] discussed the specific determination of the critical wavelengths for photoactivation, leading to the formation of glyoxylic acid, considering the capacity of two types of glass bottles (clear and dark green) to protect or limit the photodegradation of tartaric acid to glyoxylic acid. It is well known that darker colored bottles tend to give greater protection to wine from the influences of light exposure on the assumption that dark colors do not allow the transmission of UV radiation. More recently, environmental groups have proposed that the wine industry should move away from dark green to flint or amber glass bottles as a contribution towards reducing recycling costs and energy demands [17].

The Malvasia delle Lipari DOC wine (MdL) produced in the Aeolian Islands (Italy) as a liqueur wine, with minimum developed alcoholic strength of $20 \% \mathrm{v} / \mathrm{v}$, is one of the most ancient and aromatic wines of Sicily. The art. 6 of the Regulation D. P. R. 20/09/1973 "Assignment of the denomination of controlled origin of "Malvasia delle Lipari" wine" [20] describes the main characteristics of the MdL wine when it is released for consumption. The attention is also focused on the color, which must be golden yellow or amber yellow, underlining the importance of such a factor. Considering how the color could change during the storage, we focused on different colored glass bottles and different storage conditions during the shelf-life of the product.

According to production techniques, the grapes (Malvasia delle Lipari and Corinto Nero 95\% and 5\% respectively, as defined in D.P.R. 20/9/1973 [20]) are gathered when they are fully ripe and then sun-dried for 10-15 days on large mats made of bamboo canes, to reduce moisture and increase the sugar level (up to $32 \%$ ) to obtain a much more aromatic white wine [21].

In MdL, the high level of sugars and the low $\mathrm{pH}$ value suggest the possibility to develop sugar degradation products, such as 5-hydroxymethylfurfural (HMF) and 2furaldehyde $(2 \mathrm{~F})$, generally considered as indicators of heat processing and/or the prolonged storage of foods [21].

Both HMF and 2F are the most important intermediate product of the acid-catalyzed degradation of hexose and pentose, respectively, and HMF derived also from the decomposition of 3-deoxyosone during the early stage of Maillard reaction [22]. HMF is used as a quality parameter in several processed foods [23-29]. In fortified wine with different sweetness levels, the concentrations of HMF were strongly dependent on time and temperature used during winemaking, and strictly related to the sugar content of the wine [30]. Moreover, both HMF and $2 \mathrm{~F}$ are involved in the aroma of sweet, fortified white wines aged in oxygen-free conditions [31].

In recent years, several papers have debated on the safety of these compounds. HMF has been shown to be converted, in vitro and in vivo, into 5-sulfoxymethylfurfural, which has been reported to be cytotoxic, mutagenic and carcinogenic [32-34], and can be a poison for the nervous system [35]. 
The aim of this work was to study the influence of different lighting conditions, bottle color and storage temperature on the quality parameters of MdL wine: moreover, for the first time, the kinetics parameters, $k$ and $\mathrm{Ea}$, were determined for $\mathrm{HMF}$ and $2 \mathrm{~F}$ formation in sweet wine.

\section{Materials and Methods}

\subsection{Characterization of Coloured Wine Bottles}

Clear glass bottles $(200 \mathrm{~mL})$ in three different colors (colorless, green and amber) were characterized in terms of light transmission properties, measuring on five glass samples exposed to a cool-white, fluorescent lamp (Osram Lumilux ${ }^{\circledR}$ 36W /840, Munich, Germany) by a digital handle photo-radiometer (Delta OHM HD 2102.2, Delta OHM S.r.l., Caselle di Selvazzano (PD), Italy) equipped with probes for the measurement of illuminance (lux) (400-800 nm) and irradiance $\left(\mathrm{W} \mathrm{m}^{-2}\right)$ in the UVA (315-400 nm) and UVB (280-315 nm) regions. The light shielding effect offered by the packaging materials, expressed as percentage of irradiance, was calculated as:

$$
\text { Light shielding }=\mathrm{I}_{\text {sample }} / \mathrm{I}_{\text {air }} \times 100
$$

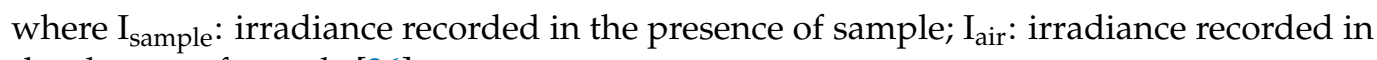
the absence of sample [36].

\subsection{Sampling}

Malvasia delle Lipari DOC wine (MdL) produced in Sicily was kindly provided by a local manufacturer. The analytical parameters $\left(\mathrm{pH},{ }^{\circ}\right.$ Brix, total acidity, volatile acidity, alcoholic strength, total phenols, CIE Lab color parameters, HMF and 2F) were determined on the wine as received, before dispensing into the previously described clear-colored glass bottles (defined as Time " 0 ").

Bottles were fulfilled ( $200 \mathrm{~mL}$ with $7 \mathrm{~mL}$ headspace), then stoppered with crown corks and stored horizontally up to six months: three months under different lighting conditions and three months under different temperature conditions. Overall, 144 bottles were considered for the study of shelf-life, according to the experimental plan reported in Table 1.

Table 1. Experimental design.

\begin{tabular}{cccc}
\hline \multicolumn{2}{c}{ Storage Conditions } & Bottle Color & Storage Time \\
\hline CWF Lamp & Temperature & & \\
\hline$n=4$ & $n=4$ & $n=3$ & $n=6$ \\
0 (control) & $25^{\circ} \mathrm{C}($ control $)$ & Colorless & 30 \\
1 & 30 & Green & 60 \\
4 & 35 & Amber & 90 \\
6 & 40 & & 120 \\
& & & 150 \\
\end{tabular}

During the first three months, the storage temperature was $25^{\circ} \mathrm{C}$. Samples were divided into three batches and exposed to different lighting conditions: (a) under constant illumination produced by one cool-white, fluorescent (CWF) lamp (Osram Lumilux ${ }^{\circledR}$ 36W /840, Munich, Germany), as to simulate the retailers conditions; (b) under constant illumination produced by four CWF lamps and (c) under constant illumination produced by six CWF lamps, in order to perform an accelerated test, by exposing the sweet wines to extreme conditions. Lamps were placed $30 \mathrm{~cm}$ above samples. Table 2 reports the illuminance (lux) and UVA and UVB irradiance $\left(\mathrm{W} \mathrm{m}^{-2}\right)$ values recorded for each selected lighting condition. 
Table 2. Measurements of illuminance (lux) and irradiance in the UVA and UVB regions ( $\mathrm{W} \mathrm{m}^{-2}$ ) recorded by digital handle photo-radiometer (values are mean of five measurements).

\begin{tabular}{cccc}
\hline Storage Condition & Illuminance (lux) & UVA $\left(\mathbf{W} \mathbf{~ m}^{-\mathbf{2}}\right)$ & UVB $\left(\mathbf{W} \mathbf{~ m}^{-\mathbf{2}}\right)$ \\
\hline 1 CWF lamp & $2671 \pm 9$ & $101.4^{-3} \pm 0.1$ & $10.71^{-3} \pm 0.03$ \\
4 CWF lamps & $9028 \pm 16$ & $284.5^{-3} \pm 0.6$ & $31.53^{-3} \pm 0.06$ \\
6 CWF lamps & $16127 \pm 13$ & $478.2^{-3} \pm 0.8$ & $53.91^{-3} \pm 0.07$ \\
\hline
\end{tabular}

After, for the next three months, MdL samples were stored under constant illumination, one cool-white, fluorescent (CWF) lamp, at three different temperatures: 30,35 and $40{ }^{\circ} \mathrm{C}$. Data loggers (Smart Reader SR04, ACR Systems Inc., Vancouver, BC, Canada) were used to monitor the storage temperatures throughout the trial.

MdL samples were periodically withdrawn at 30, 60, 90, 120, 150 and 180 days from being bottled and analyzed.

\subsection{Analytical Parameters}

Total acidity and volatile acidity, ${ }^{\circ} \mathrm{Brix}, \mathrm{pH}$ and alcohol content were determined according to the OIV official methods [37]. Chromatic characteristics (CIE Lab) were determined according to Method OIV-MA-AS2-11 [37] using a spectrophotometer (Cary $1 \mathrm{E}$, Varian, Leinì (TO) Italy) with a $1 \mathrm{~cm}$ quartz cell. The CIE parameters $\left(L^{*}, a^{*}, b^{*}, \mathrm{C}, \mathrm{h}\right)$ were determined by the "Color Calculations" spectrophotometer software (Cary WinUV 1.3, Varian, Leinì (TO) Italy).

All analyses were carried out in duplicate, using chemicals (Sigma-Aldrich, Milan, Italy) and solvents of analytical grade (J. T. Baker, Deventer, The Netherlands) and HPLC grade (Merck, Milan, Italy).

\subsection{HMF and 2-Furaldehyde}

Aliquots of MdL sample were opportunely diluted with water (JT. Baker, Deventer, Holland), filtered through a $0.45-\mu \mathrm{m}$ filter (Albet) and injected into an HPLC system (Shimadzu Class VP LC-10ADvp) equipped with a DAD (Shimadzu SPD-M10Avp, Kyoto, Japan). The column was a Gemini NX C18 $(150 \mathrm{~mm} \times 4.6 \mathrm{~mm}, 5 \mu \mathrm{m})$ (Phenomenex, Torrance, CA, USA), fitted with a guard cartridge packed with the same stationary phase. The HPLC conditions were the following: isocratic mobile phase, 90\% water (Riedelde Haën, Seelze, Germany) at 1\% of acetic acid (Merck, Darmstadt, Germany) and 10\% methanol (Scharlau, Sentmenat, Spain); flow rate, $0.7 \mathrm{~mL} / \mathrm{min}$; injection volume, $20 \mu \mathrm{L}$ [26]. The wavelength range was $220-660 \mathrm{~nm}$ and the chromatograms were monitored at 285 $\mathrm{nm}$. HMF and 2F were identified by comparison of the UV spectra and the retention time with those of HMF and 2F standard ( $p \geq 99 \%$ Sigma-Aldrich, St. Louis, MO, USA) and quantified using an external calibration curve. All analyses were performed in duplicate, including the sample dilution procedure, and the reported HMF and $2 \mathrm{~F}$ concentration is therefore the average of four values.

Kinetic parameters for $\mathrm{HMF}$ and $2 \mathrm{~F}$ formation in MdL stored under different lighting conditions and at different temperatures were calculated as reported by Arena et al. [25]. The activation energies Ea $\left(\mathrm{kcal} \mathrm{mol}^{-1}\right)$ values of $\mathrm{HMF}$ and $2 \mathrm{~F}$ were calculated from rate coefficients at different temperatures by applying the Arrhenius equation.

\subsection{Total Phenols}

The total phenols (TP) analysis was performed as reported by Di Stefano et al. [38].

Briefly, $10 \mathrm{~mL}$ of wine was diluted 1:2 with $1 \mathrm{~N} \mathrm{H}_{2} \mathrm{SO}_{4}$. Then, the diluted sample was passed through Sep Pack C18 cartridges (Waters Chromatography Europe BV, Etten-Leur, The Netherlands) previously activated with methanol and distilled water ( 2 and $5 \mathrm{~mL}$, respectively). Adsorbed phenols were washed with $2 \mathrm{~mL}$ of $0.1 \mathrm{~N} \mathrm{H}_{2} \mathrm{SO}_{4}$ and then desorbed with methanol $(3 \mathrm{~mL})$. The TP were assessed by the colorimetric Folin-Ciocalteu method at 700 and $760 \mathrm{~nm}$, with gallic acid as calibration standard. Results were expressed as $\mathrm{mg} \mathrm{L}^{-1}$. 


\subsection{Chemicals and Reagents}

All reagents and solvents HPLC grade were purchased from Merck (Darmstadt, Germany). HMF, 2F and gallic acid standards were from Sigma (Milano, Italy).

\subsection{Statistical Analysis}

Statistical analyses were performed to assess the effect of packaging and storage conditions on the analytical parameters. The significance of differences was estimated by analysis of variance (ANOVA). The statistical significance level was set to 0.05. Statistical analyses were performed using SPSS ${ }^{\circledR}$ Statistics 13.0 (IBM, Armonk, NY, USA).

Results are presented as mean value \pm standard deviation. Data were analyzed through Spearman's correlation to have a measure of the strength and direction of the association or relationship between the concentrations of analytical parameters and time of storage under different CWF lamp, and time of storage under different temperatures. All pairwise comparisons were run at $95 \%$ confidence intervals and p-values were Bonferroni adjusted through the statistical package SPSS ${ }^{\circledR}$ Statistics 13.0 (IBM, Armonk, NY, USA).

\section{Results and Discussion}

\subsection{Light Transmission Properties of Clear Glass Bottles}

Figure 1 shows the light shielding expressed as percentage. As expected, the clear, colorless bottles offered a lower shielding effect in all spectra regions considered. In particular, shielding increased in the following order: colorless $(10 \%)$, green $(26.7 \%)$ and amber (49\%) bottles for the illuminance parameter. A similar trend was observed for the UVA irradiance, while the shielding effect in the UVB region was $100 \%$ for both colored bottles and close to $90 \%$ for the clear bottle. This result is in agreement with results of Maury et al. [17], who compared the transmission spectrum of clear and green bottle colors and found that the former was capable of transmitting all visible and some UV light.

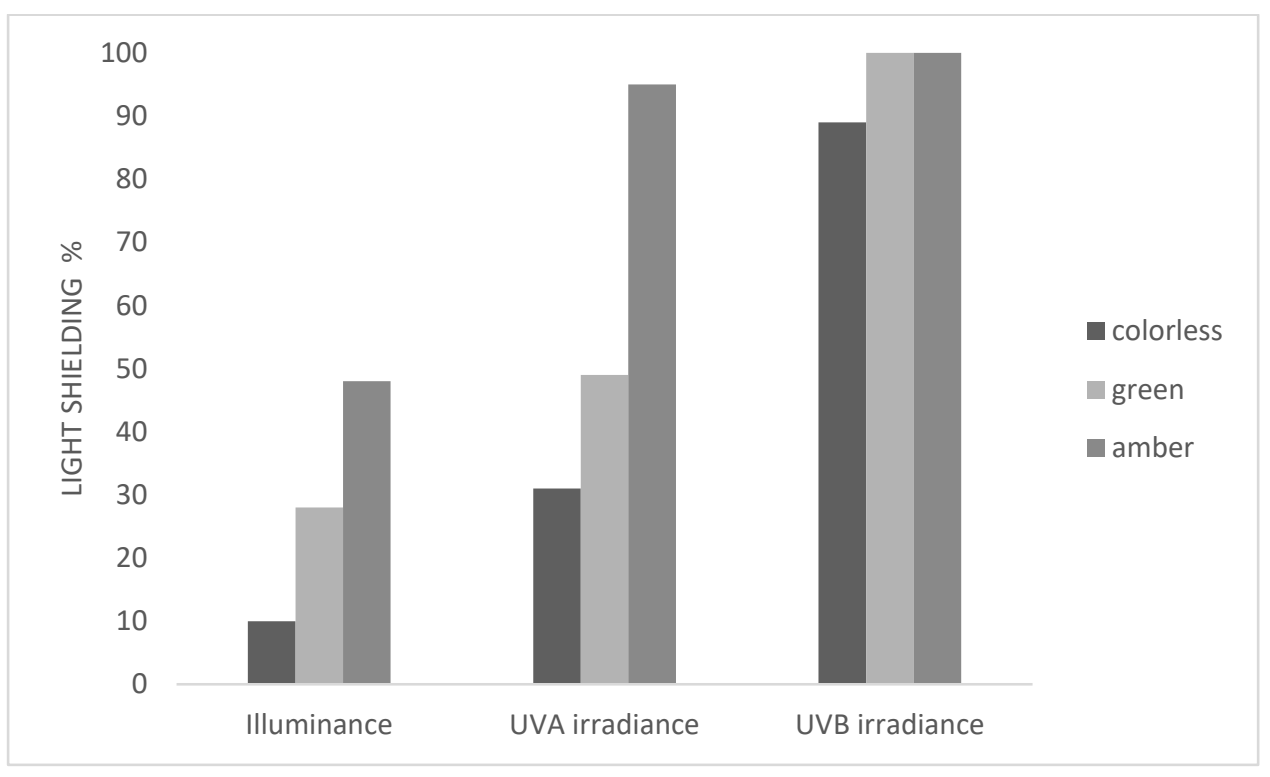

Figure 1. Light shielding (\%) of clear glass bottles (colorless, green, amber).

\subsection{Effect of Light Exposure and Bottle Color on the Quality of Malvasia Delle Lipari Wine}

MdL was characterized by the following base analytical parameters: $\mathrm{pH}=3.79$; ${ }^{\circ}$ Brix $=1.35$; total acidity $=5.4 \mathrm{~g} \mathrm{~L}^{-1}$; volatile acidity $=0.95 \mathrm{~g} \mathrm{~L}^{-1}$; alcohol content $=15.8 \%$ $(v / v) ; \mathrm{TP}=247.10 \mathrm{mg} \mathrm{L}^{-1} ; \mathrm{HMF}=1.16 \mathrm{mg} \mathrm{L}^{-1} ; 2 \mathrm{~F}=1.11 \mathrm{mg} \mathrm{L}^{-1} ; L^{*}=94.90 ; a^{*}=-2.99$; $b^{*}=17.63 ; \mathrm{C}=17.88 ; \mathrm{h}=0.17$.

Table 3 reports the changes in the quality parameters, as influenced by light exposure and glass bottle color over 90 days of storage. 


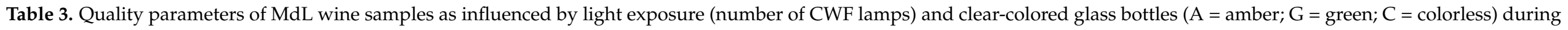



\begin{tabular}{|c|c|c|c|c|c|c|c|c|c|c|}
\hline $\begin{array}{l}\text { Time } \\
\text { (Days) }\end{array}$ & $\begin{array}{l}\text { CWF } \\
\text { Lamp }\end{array}$ & $\begin{array}{l}\text { Bottle } \\
\text { Color }\end{array}$ & TP (mg L L & C & h & $L^{*}$ & $a^{*}$ & $b^{*}$ & HMF (mg L $\left.{ }^{-1}\right)$ & $2 \mathrm{~F}\left(\mathrm{mg} \mathrm{L}^{-1}\right)$ \\
\hline \multirow{8}{*}{30} & \multirow{3}{*}{1} & $\mathrm{~A}$ & $163.90 \pm 3.40 \mathrm{mn}$ & $18.76 \pm 0.3^{\mathrm{de}}$ & $-0.11 \pm 0.02^{c}$ & $94.22 \pm 0.44^{b c}$ & $-2.14 \pm 0.06^{\mathrm{b}}$ & $18.63 \pm 0.07$ de & $2.08 \pm 0.07 \mathrm{~g}$ & $1.02 \pm 0.04^{\mathrm{f}}$ \\
\hline & & G & $168.62 \pm 0.88^{1}$ & $18.06 \pm 1.1^{\mathrm{e}}$ & $-0.09 \pm 0.01^{\mathrm{cd}}$ & $93.78 \pm 0.55^{\mathrm{bcd}}$ & $-1.62 \pm 0.00^{\mathrm{a}}$ & $17.99 \pm 0.15^{\mathrm{e}}$ & $2.23 \pm 0.07^{g}$ & $1.24 \pm 0.08^{\text {ef }}$ \\
\hline & & $\mathrm{C}$ & $158.31 \pm 0.46^{\circ}$ & $17.41 \pm 0.4^{\mathrm{e}}$ & $-0.12 \pm 0.01 \mathrm{bc}$ & $94.60 \pm 0.69 \mathrm{bc}$ & $-2.01 \pm 0.04^{\mathrm{b}}$ & $17.29 \pm 0.38^{\mathrm{e}}$ & $1.89 \pm 0.08 \mathrm{gh}$ & $1.32 \pm 0.09^{\mathrm{e}}$ \\
\hline & \multirow{3}{*}{4} & $\mathrm{~A}$ & $179.40 \pm 2.25^{\mathrm{i}}$ & $19.97 \pm 0.4^{\mathrm{d}}$ & $-0.12 \pm 0.2^{b c}$ & $93.69 \pm 0.92 \mathrm{bcd}$ & $-2.38 \pm 0.08 \mathrm{bc}$ & $19.82 \pm 1.18^{d}$ & $4.62 \pm 0.05$ ef & $1.57 \pm 0.09^{\mathrm{d}}$ \\
\hline & & G & $160.94 \pm 1.33^{\mathrm{m}}$ & $19.06 \pm 0.0^{\mathrm{d}}$ & $-0.11 \pm 0.01^{\mathrm{c}}$ & $95.04 \pm 2.56^{\mathrm{b}}$ & $-2.00 \pm 0.20^{b}$ & $18.96 \pm 0.68$ de & $3.51 \pm 0.08^{\mathrm{fg}}$ & $1.90 \pm 0.09^{c}$ \\
\hline & & $\mathrm{C}$ & $144.06 \pm 2.01 \mathrm{p}$ & $18.79 \pm 1.4^{\mathrm{de}}$ & $-0.16 \pm 0.3^{a b}$ & $94.79 \pm 1.32 \mathrm{bc}$ & $-3.00 \pm 0.42^{b c}$ & $18.55 \pm 1.66^{\mathrm{de}}$ & $3.75 \pm 0.07^{\mathrm{fg}}$ & $1.50 \pm 0.07^{\mathrm{ed}}$ \\
\hline & \multirow{2}{*}{6} & $\mathrm{~A}$ & $193.26 \pm 4.21^{\mathrm{gh}}$ & $19.81 \pm 2.0^{\mathrm{d}}$ & $-0.11 \pm 0.01^{c}$ & $93.23 \pm 0.34 \mathrm{bcd}$ & $-2.07 \pm 0.01^{\mathrm{b}}$ & $19.70 \pm 0.49^{\mathrm{d}}$ & $4.23 \pm 0.05^{f}$ & $1.85 \pm 0.09^{c}$ \\
\hline & & $\mathrm{C}$ & $192.51 \pm 2.06^{\mathrm{gh}}$ & $18.13 \pm 0.2 \mathrm{de}$ & $-0.16 \pm 0.1^{\mathrm{ab}}$ & $94.73 \pm 0.51 \mathrm{bc}$ & $-2.95 \pm 0.39 b c$ & $17.89 \pm 0.54^{\mathrm{e}}$ & $3.98 \pm 0.07^{\text {efg }}$ & $1.34 \pm 0.09^{\mathrm{e}}$ \\
\hline \multirow{7}{*}{60} & \multirow{3}{*}{1} & A & $190.58 \pm 0.94 \mathrm{~g}$ & $22.33 \pm 0.1^{c}$ & $-0.17 \pm 0.2^{\mathrm{ab}}$ & $94.31 \pm 0.02^{b c}$ & $-3.75 \pm 0.01^{\mathrm{cd}}$ & $22.01 \pm 0.00^{c}$ & $4.26 \pm 0.47^{\mathrm{f}}$ & $1.06 \pm 0.01^{\mathrm{f}}$ \\
\hline & & G & $189.52 \pm 1.10 \mathrm{~g}$ & $21.74 \pm 0.1^{\mathrm{cd}}$ & $-0.16 \pm 0.01 \mathrm{ab}$ & $94.23 \pm 0.00^{b c}$ & $-3.41 \pm 0.00^{c}$ & $21.47 \pm 0.01^{\mathrm{cd}}$ & $4.28 \pm 0.20^{\mathrm{f}}$ & $1.62 \pm 0.33^{\mathrm{d}}$ \\
\hline & & $\mathrm{C}$ & $225.34 \pm 2.95^{c}$ & $21.02 \pm 2.3^{c d}$ & $-0.18 \pm 0.0 .14^{\mathrm{a}}$ & $94.79 \pm 0.01 \mathrm{bc}$ & $-3.70 \pm 0.01^{c d}$ & $20.70 \pm 0.02^{c d}$ & $3.68 \pm 0.12^{\mathrm{fg}}$ & $1.70 \pm 0.22^{\mathrm{cd}}$ \\
\hline & \multirow{3}{*}{4} & $\mathrm{~A}$ & $205.22 \pm 4.21^{\mathrm{f}}$ & $24.83 \pm 0.4^{b c}$ & $-0.20 \pm 0.1^{\mathrm{a}}$ & $95.29 \pm 0.14^{b}$ & $-4.90 \pm 0.02 \mathrm{de}$ & $24.34 \pm 0.01^{b c}$ & $18.56 \pm 0.37^{c}$ & $2.03 \pm 0.26^{\mathrm{bc}}$ \\
\hline & & G & $210.42 \pm 3.05^{\mathrm{e}}$ & $24.61 \pm 2.1^{b c}$ & $-0.18 \pm 0.1^{\mathrm{a}}$ & $94.54 \pm 0.10^{b c}$ & $-4.25 \pm 0.01^{\mathrm{d}}$ & $24.24 \pm 0.00 \mathrm{bc}$ & $12.65 \pm 2.24^{\mathrm{cd}}$ & $2.65 \pm 0.04^{b c}$ \\
\hline & & $\mathrm{C}$ & $220.26 \pm 0.45^{\mathrm{d}}$ & $22.83 \pm 0.1^{c}$ & $-0.19 \pm 0.02^{\mathrm{a}}$ & $95.18 \pm 0.10^{\mathrm{b}}$ & $-4.31 \pm 0.31^{\mathrm{d}}$ & $22.42 \pm 0.30^{c}$ & $14.01 \pm 0.93^{\mathrm{cd}}$ & $2.23 \pm 0.04^{b c}$ \\
\hline & 6 & $\mathrm{~A}$ & $210.22 \pm 2.01^{\mathrm{e}}$ & $24.03 \pm 0.4^{b c}$ & $-0.18 \pm 0.1^{\mathrm{a}}$ & $94.62 \pm 0.01^{b c}$ & $-4.19 \pm 0.00^{\mathrm{d}}$ & $23.32 \pm 0.02^{b c}$ & $11.37 \pm 1.04^{\mathrm{cd}}$ & $2.92 \pm 0.53 \mathrm{ab}$ \\
\hline \multirow{9}{*}{90} & \multirow{3}{*}{1} & $\mathrm{~A}$ & $236.10 \pm 0.70^{\mathrm{b}}$ & $29.59 \pm 0.4^{\mathrm{ab}}$ & $-0.11 \pm 0.1^{c}$ & $91.89 \pm 0.21^{\mathrm{d}}$ & $-3.20 \pm 0.23^{c d}$ & $29.42 \pm 0.11^{\mathrm{ab}}$ & $7.81 \pm 1.21^{\mathrm{e}}$ & $1.70 \pm 0.09^{\mathrm{cd}}$ \\
\hline & & G & $216.32 \pm 1.74 \mathrm{de}$ & $26.28 \pm 0.1^{\mathrm{b}}$ & $-0.15 \pm 0.1^{\mathrm{b}}$ & $93.49 \pm 0.20 \mathrm{bcd}$ & $-3.96 \pm 0.12^{\mathrm{cd}}$ & $25.98 \pm 0.20^{b}$ & $9.92 \pm 0.87 \mathrm{de}$ & $1.81 \pm 0.02^{\mathrm{c}}$ \\
\hline & & $\mathrm{C}$ & $297.54 \pm 0.40^{\mathrm{a}}$ & $26.64 \pm 0.2^{b}$ & $-0.14 \pm 0.1^{b c}$ & $93.35 \pm 0.20 \mathrm{bcd}$ & $-3.76 \pm 0.14^{c d}$ & $26.37 \pm 0.41^{b}$ & $8.35 \pm 0.47^{\mathrm{de}}$ & $1.68 \pm 0.18^{\mathrm{cd}}$ \\
\hline & \multirow{3}{*}{4} & $\mathrm{~A}$ & $227.30 \pm 3.74^{c}$ & $32.05 \pm 0.4^{\mathrm{a}}$ & $-0.16 \pm 0.1^{\mathrm{ab}}$ & $93.08 \pm 0.22 \mathrm{bcd}$ & $-4.95 \pm 0.11 \mathrm{de}$ & $31.66 \pm 0.30^{\mathrm{ab}}$ & $26.82 \pm 0.87^{b}$ & $3.26 \pm 0.05^{a}$ \\
\hline & & G & $228.84 \pm 2.31^{c}$ & $29.94 \pm 0.5^{\mathrm{ab}}$ & $-0.15 \pm 0.01^{b}$ & $93.01 \pm 0.30 \mathrm{bcd}$ & $-4.31 \pm 0.10^{\mathrm{d}}$ & $29.62 \pm 0.21 \mathrm{ab}$ & $27.35 \pm 0.38^{b}$ & $2.97 \pm 0.21 \mathrm{ab}$ \\
\hline & & $\mathrm{C}$ & $236.14 \pm 1.08^{b}$ & $35.94 \pm 1.4^{\mathrm{a}}$ & $-0.04 \pm 0.01^{\mathrm{d}}$ & $88.12 \pm 0.43^{\mathrm{de}}$ & $-1.60 \pm 0.00^{\mathrm{a}}$ & $35.90 \pm 0.20^{\mathrm{a}}$ & $26.58 \pm 0.85^{b}$ & $3.58 \pm 0.15^{a}$ \\
\hline & \multirow{3}{*}{6} & $\mathrm{~A}$ & $224.31 \pm 0.85^{\mathrm{cd}}$ & $30.24 \pm 2.1^{\mathrm{ab}}$ & $-0.16 \pm 0.1^{\mathrm{ab}}$ & $93.39 \pm 0.51 \mathrm{bcd}$ & $-4.84 \pm 0.31 \mathrm{de}$ & $29.85 \pm 1.10^{\mathrm{ab}}$ & $36.43 \pm 0.97^{\mathrm{a}}$ & $3.00 \pm 0.10^{\mathrm{ab}}$ \\
\hline & & $\mathrm{G}$ & $220.57 \pm 2.45^{\mathrm{d}}$ & $28.03 \pm 0.2^{a b}$ & $-0.15 \pm 0.1^{\mathrm{b}}$ & $92.78 \pm 0.20^{\mathrm{d}}$ & $-4.26 \pm 0.30^{\mathrm{d}}$ & $27.70 \pm 1.00^{b}$ & $33.74 \pm 0.10^{\mathrm{ab}}$ & $2.82 \pm 0.06^{b}$ \\
\hline & & $\mathrm{C}$ & $204.18 \pm 1.04^{f}$ & $25.39 \pm 0.4^{b c}$ & $-0.17 \pm 0.1^{\mathrm{ab}}$ & $94.26 \pm 0.90^{b c}$ & $-4.35 \pm 0.33^{d}$ & $25.01 \pm 1.5^{\mathrm{b}}$ & $30.75 \pm 0.90^{\mathrm{ab}}$ & $3.04 \pm 0.18^{a b}$ \\
\hline
\end{tabular}


Comparing the values of volatile acidity and $\mathrm{pH}$ at time " 0 ", both parameters showed the same course in all clear-colored glass bottles under all lighting conditions, with a slight decrease for volatile acidity up to $0.82 \pm 0.02 \mathrm{~g} \mathrm{~L}^{-1}$. Total acidity ranged between $5.40 \pm 0.34 \mathrm{~g} \mathrm{~L}^{-1}$ and $5.23 \pm 0.06 \mathrm{~g} \mathrm{~L}^{-1}$ in all clear-colored glass bottles; samples bottled in clear colorless glass showed the same trend under 1, 4 and 6 CWF lamp lighting. Overall, small variations were observed during the shelf-life tests for $\mathrm{pH}$, volatile and total acidity, but no statistical significance was observed $(p>0.05)$. Similarly, Revi et al. [18] as well as Hopfer et al. [39] found no differences $(p>0.05)$ in total and volatile acidity, $\mathrm{pH}$ and ethanol content of Chardonnay wine between bag-in-box containers and glass screw cap bottles after three months of storage at $20^{\circ} \mathrm{C}$.

Arapitsas et al. [40], studying white wine light-strike fault in flint and green glass bottles, reported any statistically significant difference among $\mathrm{pH}$, titratable acidity and volatile acidity, and as the last one was not affected by time or packaging choice.

The trend for the TP during storage was the same for all clear-colored glass bottles and lighting conditions tested, reaching a mean value of $249.11 \pm 18.66 \mathrm{mg} \mathrm{L}^{-1}$ after 90 days.

These results are discordant with previous observations where we noticed a reduction in TP during wine ageing, explained by the transformation and/or precipitation of phenolic material as oxidation reactions progress [41].

In MdL, this parameter did not change significantly, neither with different light exposure, nor with storage time $(p>0.05)$.

Color is one of the major attributes that affects the consumer perception of quality. Small changes in CIE parameters were observed. In particular, C, hue and $b^{*}$ progressively increased at each lighting condition, from 0 to 90 days of the study. For instance, C changed during the storage time by a percentage of 11,39 and $79 \%$ after 30, 60 and 90 days, respectively, in amber bottles under 4 CWF lamps. Similarly, the change ranged to about 7 , 37 and $67 \%$ after 30, 60 and 90 days, respectively, in green bottles under 4 CWF lamps and up to $100 \%$ for colorless bottles under the same lighting. The $b^{*}$ value increased proportionally through the storage period with the increasing number of CWF lamps, with R2 0.87, 0.90 and 0.95 after 30, 60 and 90 days, respectively. The increase in $b^{*}$ values represents a higher intensity of yellow and the main increase is always in amber bottles, with only the exception of colorless bottles observed after 90 days and exposed under 4 CWF lamps. The $L^{*}$ values, which give a value of the brightness of the samples, slightly decrease during 90 days of storage, until the $2-3 \%$ of reduction from the initial value for clear green and clear amber bottles under 6 and 1 CWF lamps respectively, while the decrease is near the $8 \%$ in colorless bottles exposed at 4 CWF lamps. The $a^{*}$ value, which represents the degree of one component of green color, had a reduction during the first 30 days, and then an increase was observed after 60 days of storage under illumination, especially in clear amber bottles stored under 4 CWF lamps, according to Refsgaard et al. [42], while MdL stored in clear green bottles did not show any particular differences from the beginning. Hue (h), the attribute of appearance by which a color is identified according to its resemblance to red, green, yellow or blue, slightly decreases from 30 to 90 days. An increase in the yellow color $\left(b^{*}\right)$ and hue is usually associated with wine aging, as well as a decrease in $a^{*}$, measured in light-exposed samples [43].

The HMF content showed a similar trend for the clear amber, green and colorless bottles, while some differences were observed when MdL was stored under different lighting conditions, mostly at 4 and 6 CWF lamps. In these cases, a rapid HMF increase was observed in the first 60 days, up to $18.56 \pm 0.37 \mathrm{mg} \mathrm{L}^{-1}$, with a progressive increase over the following 30 days, up to $36.43 \pm 0.97 \mathrm{mg} \mathrm{L}^{-1}$ (Table 3). Based on two-way ANOVA, the interaction effect of bottle color $\times$ lighting conditions on HMF concentration was not significant, while a significant effect $(p<0.001)$ was found for the lighting conditions, as expressed with different letters in Figure 2. It is well known that several factors influence the formation rate of this compound, such as temperature, time and storage conditions [26], as well as sugar concentration and water activity [44]. HMF reacted with ethanol to form 5-(ethoxymethyl) furfural, a compound founded in sweet fortified white wine, with a 
concentration above of the perception threshold, after 6 months of aging, in the absence of air [45].

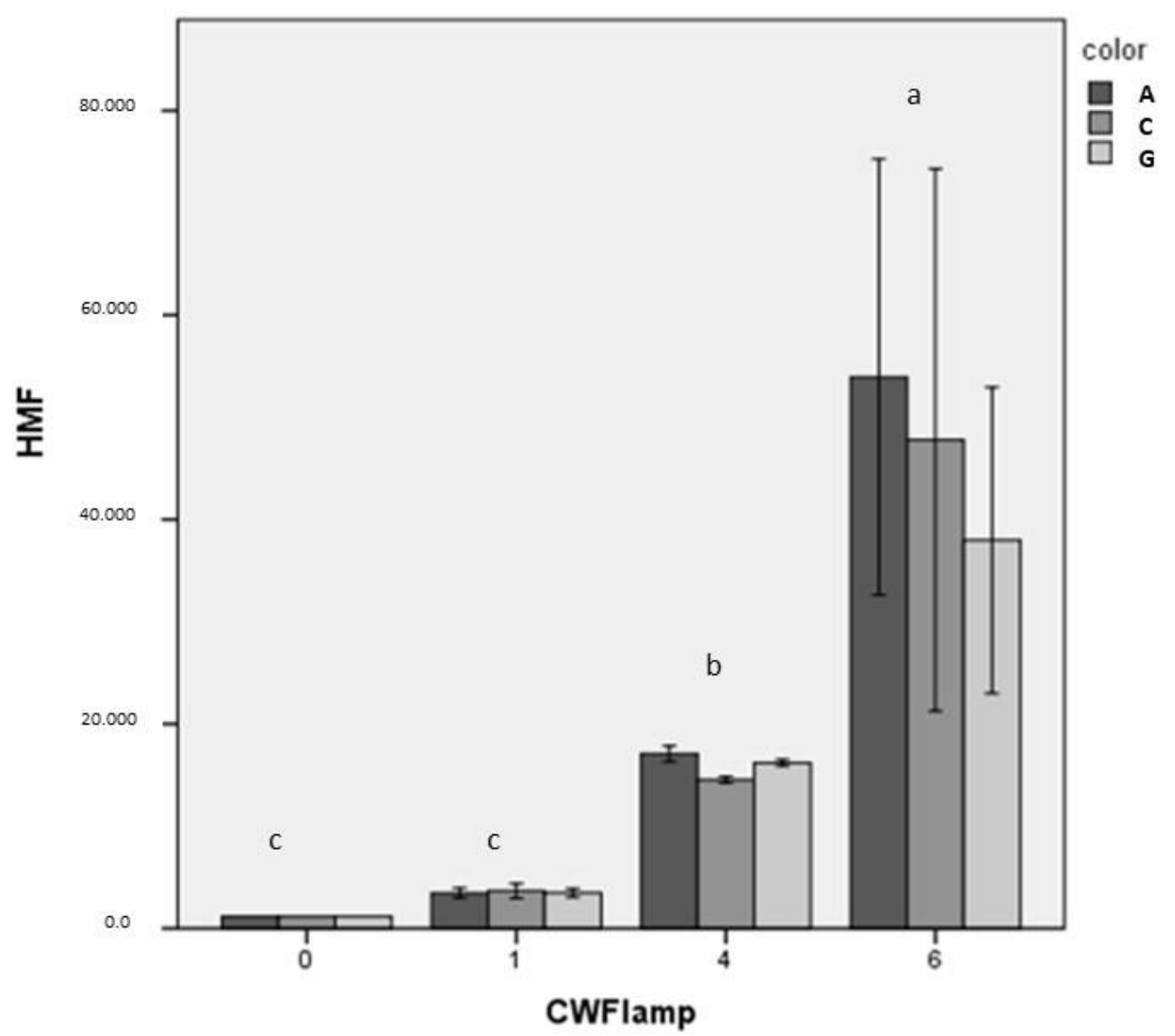

Figure 2. HMF concentration at constant temperature of $25^{\circ} \mathrm{C}$ influenced by the number of CWF lamps $(0,1,4,6)$ and the color of clear glass bottles (amber, colorless, green); different letters represent significant differences (LSD test, $p \leq 0.05$ ).

As concerns 2F, produced by breakdown of pentose and/or Maillard reaction, from the starting value of $2 \mathrm{~F}\left(1.11 \mathrm{mg} \mathrm{L}^{-1}\right)$, an increase in the $2 \mathrm{~F}$ concentration was observed in samples kept under 4 and 6 CWF lamps, until the final values were $3.3 \pm 0.3 \mathrm{mg} \mathrm{L}^{-1}$ and $2.9 \pm 0.2 \mathrm{mg} \mathrm{L}^{-1}$, respectively. Similarly to HMF, a statistically significant effect of lighting on $2 \mathrm{~F}$ concentration was observed $\mathrm{F}\left(3.30=5.473, p=0.007\right.$, partial $\left.\eta^{2}=0.477\right)$.

A two-way ANOVA was conducted to examine the effects of the exposure to a different number of CWF lamps, and the color of the glass bottles on each dependent variable examined (total and volatile acidity, TP, HMF, 2F, color parameter and $\mathrm{pH}$ ). Residual analysis was performed to test for the assumptions of the two-way ANOVA. Outliers were assessed by inspection of a boxplot, then data were verified for the non-normality and homogeneity of variances. Normality was assessed using Shapiro-Wilk's normality test for each cell of the design, and the homogeneity of variances was assessed by Levene's test.

The interaction effect between CWF lamps and bottle color (Table 3) on volatile acidity, $\mathrm{TP}$, Chroma, Hue and $\mathrm{pH}$, was not statistically significant ( $F$-test-degrees of freedom for the interaction term 6 in $(6,69))$. Finding a non-statistically significant interaction does not mean that an interaction effect does not exist. Therefore, an analysis of the main effect for a kind of lighting (number of CWF lamp) was performed, which indicated that the main effect was not statistically significant $(p>0.05)$. All pairwise comparisons run where reported $95 \%$ confidence intervals and $p$-values are Bonferroni-adjusted.

At constant temperature, a Spearman's rank-order correlation (2-tailed) was run to assess the relationship between HMF and 2F concentration, with storage time under 1, 
4 and 6 CWF lamp. Preliminary analysis showed the relationship to be monotonic, as assessed by the visual inspection of a scatterplot. There was a strong positive correlation between HMF and the number of CWF lamps, $r_{s}=0.846, p<0.01$ (Figure 2); as well as a positive correlation between $2 \mathrm{~F}$ and storage time, $r_{s}=0.429, p<0.05$.

Table 4 reports the kinetics parameters of both HMF and $2 \mathrm{~F}$ formation in MdL wine stored under different lighting conditions. All systems fit a pseudo-first-order equation [46] well, and $k$ values for HMF formation were always higher respect to those determined for $2 \mathrm{~F}$ formation, regardless of bottle color and lighting conditions.

The MdL samples stored under 1 CWF lamp showed the lowest $k$ values for HMF formation (about 0.017 days $^{-1}$ ) independently from the bottle color. As the light exposure increases from 1 to 4 CWF lamps, the $k$ value for HMF formation increases up to about 0.034 days $^{-1}$ and was similar to those determined for MdL stored under 6 CWF lamps (about 0.031 days $^{-1}$ ).

Similarly to HMF, $2 \mathrm{~F}$ shows the lowest $k$ value under 1 CWF lamp, while it increased by 2.6 fold under the lightening of 4 and 6 CWF lamp, independently of the bottle color.

Table 4. Kinetics parameters for HMF and 2-furaldehyde formation in MdL stored in clear-colored glass bottles (amber, green, colorless) under different lighting condition (at constant temperature $\left.\mathrm{T}=25 \pm 2{ }^{\circ} \mathrm{C}\right)$. (Control was a sample kept in the dark).

\begin{tabular}{ccccccc}
\hline \multicolumn{7}{c}{ 5-Hydroxymethylfurfural } \\
& \multicolumn{1}{c}{$\mathbf{1}$ CWF Lamp } & \multicolumn{2}{c}{ 4 CWF Lamps } & \multicolumn{2}{c}{ 6 CWF Lamps } \\
\cline { 2 - 7 } & $\boldsymbol{k}$ (min) & $\boldsymbol{R}^{\mathbf{2}}$ & $\boldsymbol{k}$ (min) & $\boldsymbol{R}^{\mathbf{2}}$ & $\boldsymbol{k}$ (min) & $\boldsymbol{R}^{\mathbf{2}}$ \\
\hline Control & 0.0116 & 0.91296 & 0.0116 & 0.91296 & 0.0116 & 0.91296 \\
Amber & 0.0164 & 0.95525 & 0.0363 & 0.98405 & 0.0316 & 0.99903 \\
Green & 0.0183 & 0.95012 & 0.0333 & 0.98975 & 0.0315 & 0.99805 \\
Colorless & 0.016 & 0.90128 & 0.0333 & 0.98967 & 0.0312 & 0.99953 \\
\hline \multicolumn{7}{c}{ 2-Furaldehyde } \\
\hline Control & 0.0044 & 0.7529 & 0.0044 & 0.7529 & 0.0044 & 0.7529 \\
Amber & 0.0048 & 0.9999 & 0.0115 & 0.9855 & 0.013 & 0.8765 \\
Green & 0.0056 & 0.967 & 0.0125 & 0.8969 & 0.0111 & 0.9769 \\
Colorless & 0.0054 & 0.8776 & 0.0125 & 0.9878 & 0.0101 & 0.9429 \\
\hline
\end{tabular}

\subsection{Effect of Storage Temperature on Quality Changes of Malvasia Delle Lipari Wine}

After the first 90 days, samples were stored up to 180 days under constant illumination (one CWF lamp) at three different temperatures: 30,35 and $40^{\circ} \mathrm{C}$ (Table 5).

The $\mathrm{pH}$ value was stable during the first 90 days of the study, showing a slight decrease, reaching 180 days, especially at $30^{\circ} \mathrm{C}$ and $35^{\circ} \mathrm{C}$, reaching values of 3.31 and 3.29 respectively; in addition, volatile acidity showed only slight changes and limited standard deviation.

The TP content at the end of the study was practically coincident with the initial values, notwithstanding the oscillations observed during the trials.

The Chroma (C) is the measure of a stimulus judged relative to the white. Chroma, hue and $b^{*}$ followed the same path. Initial $C$ value was 35.10 and its value increased from 90 to 180 days until an average value of $46.00 \pm 8.30$ among the three temperatures. $C$ values increased with storage temperature, in the order: 30,35 and $40^{\circ} \mathrm{C}$. No significant change was observed for $L^{*}$. The $a^{*}$ value was stable for the first 150 days to increase in samples at $35^{\circ} \mathrm{C}$ and $40^{\circ} \mathrm{C}$. From 150 to 180 days, an increase was also monitored in MdL stored at $30^{\circ} \mathrm{C}$, exceeding the values of all the other samples. As previously reported, an increase in color parameters is linked to light-exposed samples [43]. 
Table 5. Evolution of quality parameters of MdL wine samples at different storage temperatures $\left(30,35,40{ }^{\circ} \mathrm{C}\right)(\mathrm{HMF}$ : 5-hydroxymethylfurfural; 2F: 2-furaldehyde; TP: total phenols; C: chroma; h: hue; L*: lightness) from 90 to 180 days.

\begin{tabular}{|c|c|c|c|c|c|c|c|}
\hline $\begin{array}{l}\text { Time } \\
\text { (Days) }\end{array}$ & $\begin{array}{c}\mathrm{T} \\
{ }^{\circ} \mathrm{C}\end{array}$ & $\begin{array}{c}\text { HMF } \\
\mathrm{mg} \mathrm{L}^{-1}\end{array}$ & $\begin{array}{c}2 \mathrm{~F} \\
\mathrm{mg} \mathrm{L}^{-1}\end{array}$ & $\begin{array}{c}\mathrm{TP} \\
\mathrm{mg} \mathrm{L}^{-1}\end{array}$ & $\mathrm{C}$ & h & $L^{*}$ \\
\hline \multirow{3}{*}{90} & 30 & $8.69 \pm 1.10^{h}$ & $1.73 \pm 0.07^{\mathrm{e}}$ & $259.12 \pm 1.62 b c$ & $31.95 \pm 0.70 \mathrm{~g}$ & $-0.14 \pm 0.00^{\mathrm{a}}$ & $92.15 \pm 0.27^{\mathrm{a}}$ \\
\hline & 35 & $26.92 \pm 0.40 \mathrm{fgh}$ & $3.27 \pm 0.30$ cde & $263.92 \pm 9.23 b c$ & $37.61 \pm 2.97 \mathrm{de}$ & $-0.12 \pm 0.00 \mathrm{bc}$ & $91.13 \pm 0.49^{a}$ \\
\hline & 40 & $33.64 \pm 2.84 \mathrm{fg}$ & $2.95 \pm 0.12^{\text {de }}$ & $250.02 \pm 9.06^{c}$ & $35.75 \pm 3.46^{\mathrm{e}}$ & $-0.12 \pm 0.00 \mathrm{bc}$ & $90.88 \pm 0.86^{a b}$ \\
\hline \multirow{3}{*}{120} & 30 & $17.60 \pm 0.56^{\mathrm{gh}}$ & $2.10 \pm 0.54^{\mathrm{e}}$ & $257.62 \pm 26.1^{b c}$ & $33.19 \pm 0.15^{\text {ef }}$ & $-0.13 \pm 0.01^{\mathrm{ab}}$ & $91.98 \pm 0.49^{\mathrm{a}}$ \\
\hline & 35 & $55.86 \pm 2.19 \mathrm{de}$ & $3.71 \pm 0.33^{\text {cde }}$ & $249.62 \pm 10.6^{c d}$ & $41.82 \pm 0.41^{\mathrm{c}}$ & $-0.10 \pm 0.01^{\mathrm{cd}}$ & $90.00 \pm 0.39^{a b}$ \\
\hline & 40 & $68.23 \pm 3.50^{\mathrm{d}}$ & $4.71 \pm 0.31^{\mathrm{bcd}}$ & $284.77 \pm 0.90^{a}$ & $38.47 \pm 0.31^{\mathrm{d}}$ & $-0.11 \pm 0.01^{\mathrm{c}}$ & $90.13 \pm 1.33^{a b}$ \\
\hline \multirow{3}{*}{150} & 30 & $29.70 \pm 1.18^{\mathrm{fg}}$ & $1.88 \pm 0.19^{\mathrm{e}}$ & $231.00 \pm 4.53^{\text {ef }}$ & $34.62 \pm 1.11^{\text {ef }}$ & $-0.13 \pm 0.02^{a b}$ & $91.64 \pm 0.48^{a}$ \\
\hline & 35 & $101.43 \pm 3.0^{\mathrm{c}}$ & $5.24 \pm 0.45^{\mathrm{abc}}$ & $234.76 \pm 30.48^{\mathrm{e}}$ & $50.58 \pm 1.94^{\mathrm{ab}}$ & $-0.06 \pm 0.02 \mathrm{e}$ & $87.89 \pm 1.13^{b c}$ \\
\hline & 40 & $107.25 \pm 9.7^{b c}$ & $5.07 \pm 0.32^{\mathrm{abcd}}$ & $246.72 \pm 3.44^{\mathrm{cd}}$ & $41.04 \pm 4.32^{\mathrm{c}}$ & $-0.09 \pm 0.00^{\mathrm{d}}$ & $89.86 \pm 0.28^{b}$ \\
\hline \multirow{3}{*}{180} & 30 & $37.13 \pm 1.86^{\text {ef }}$ & $2.02 \pm 0.31^{\mathrm{e}}$ & $238.42 \pm 10.37^{\mathrm{d}}$ & $40.76 \pm 7.42^{\mathrm{cd}}$ & $-0.06 \pm 0.11^{\mathrm{e}}$ & $87.24 \pm 8.10^{b c}$ \\
\hline & 35 & $124.49 \pm 15.54^{b}$ & $7.17 \pm 1.76^{\mathrm{a}}$ & $269.92 \pm 16.60^{a b}$ & $55.57 \pm 5.52^{a}$ & $0.05 \pm 0.12^{\mathrm{e}}$ & $76.26 \pm 15.5^{d}$ \\
\hline & 40 & $152.81 \pm 12.18^{a}$ & $6.32 \pm 1.69^{a b}$ & $239.00 \pm 6.00^{d}$ & $41.67 \pm 4.92^{\mathrm{c}}$ & $-0.10 \pm 0.02^{\mathrm{cd}}$ & $89.60 \pm 1.34^{b}$ \\
\hline
\end{tabular}

Different letters within the same parameter and main factor show significant differences (LSD test, $p \leq 0.05$ ).

The HMF levels changed considerably, mostly when MdL was stored at the highest temperature. At $30^{\circ} \mathrm{C}$, the HMF content increased from about $9 \mathrm{mg} / \mathrm{kg}$ up to $37 \mathrm{mg} / \mathrm{kg}$ at 180 days of storage. At $35^{\circ} \mathrm{C}$, the HMF content increased up to about $125 \mathrm{mg} / \mathrm{kg}$ at the end of storage. The effect of temperature on HMF formation, obviously, was more evident at $40{ }^{\circ} \mathrm{C}$. At this storage, the HMF increases rapidly, even after 120 days, and at 180 days of storage, reached the highest levels, about $153 \mathrm{mg} / \mathrm{kg}$.

During MdL storage at 30 and $35^{\circ} \mathrm{C}, 2 \mathrm{~F}$ increased slowly and important changes were only founded at $40^{\circ} \mathrm{C}$. At this temperature, after 180 days of storage, the $2 \mathrm{~F}$ concentration was about 3 times higher than that determined at $30^{\circ} \mathrm{C}$.

Moreover, HMF levels were always higher than $2 \mathrm{~F}$. The first furanic compound was derived from glucose and fructose, while $2 \mathrm{~F}$ comes from pentoses present in wine, in minor amounts. This trend was reported by other authors in sweet wine [30].

To underline changes related to different storage temperatures, a Spearman's rankorder correlation was carried out to assess the relationship between color parameters, HMF and $2 \mathrm{~F}$ concentration, with storage time under different temperatures. Preliminary analysis showed the relationship to be monotonic, as assessed by visual inspection of a scatterplot. There were strong positive correlations $(p<0.01)$ between: HMF and $2 \mathrm{~F}, r_{s}=0.972 ; \mathrm{HMF}$ and temperatures, $r_{s}=0.798 ; 2 \mathrm{~F}$ and temperatures, $r_{s}=0.739$ as reported in Table 6 (the correlation between $C$ and all the color parameters was significant for $p<0.01$ ).

Table 7 shows the kinetic parameters $k\left(\right.$ days $\left.^{-1}\right)$, and the activation energy (Ea), both for $\mathrm{HMF}$ and $2 \mathrm{~F}$ formation, in MdL wine stored at different temperatures. Concerning $\mathrm{HMF}$, the lowest $k$ value was determined at $30{ }^{\circ} \mathrm{C}\left(0.0144\right.$ days $\left.{ }^{-1}\right)$, and the highest was found at $40{ }^{\circ} \mathrm{C}\left(0.0167\right.$ days $\left.^{-1}\right)$.

The kinetics for $2 \mathrm{~F}$ formation exhibited a $k$ value lower than those of $\mathrm{HMF}$, ranging from 0.0038 to 0.0088 days $^{-1}$, at 30 and $40^{\circ} \mathrm{C}$, respectively.

Cutzach et al. [45] studied the formation of some compounds, including HMF and 2F, during the aging of sweet fortified wines at the temperature of $37^{\circ} \mathrm{C}$. Data reported in this work concerning $\mathrm{HMF}$ and $2 \mathrm{~F}$ were used to determine $k$ value, in order to compare our data with those reported in literature. Furthermore, in this case, $k$ value was lowest for $2 \mathrm{~F}$ formation and highest for HMF formation and kinetic parameters were very similar to our data $\left(2 \mathrm{~F}, k=0.0099\right.$ days $^{-1}, R^{2}=0.987 ; \mathrm{HMF}, k=0.0136$ days $\left.^{-1}, R^{2}=0.992\right)$, suggesting a similar mechanisms of reactions.

As concerns the activation energy (Table 7), the lowest value was determined for HMF $\left(11.7 \mathrm{~kJ} \mathrm{~mol}^{-1}\right)$, and the highest, about 5.7-fold higher than HMF, for 2F formation 
$\left(66.4 \mathrm{~kJ} \mathrm{~mol}^{-1}\right)$, suggesting that a small increase of temperature induced a fast increase of the formation of these compounds, mostly for HMF.

Table 6. Spearman's rho $\mathrm{T}=30-35-40{ }^{\circ} \mathrm{C}$ from 90 to 180 days of storage $(N=12)$. (HMF: 5-hydroxymethylfurfural; 2F: 2-furaldehyde: C: chroma; h: hue; $L^{*}$ : lightness; $a^{*}$ : redness; $b^{*}$ : yellowness).

\begin{tabular}{|c|c|c|c|c|c|c|c|c|}
\hline & & HMF & 2-Furaldehyde & $\mathrm{C}$ & $\mathbf{h}$ & $L^{*}$ & $a^{*}$ & $b^{*}$ \\
\hline \multirow[t]{2}{*}{$\begin{array}{c}\text { Time } \\
\text { (days) }\end{array}$} & Correlation coefficient & $0.518 *$ & 0.497 & $0.626^{*}$ & $0.718^{* *}$ & $-0.777 *$ & $0.791 * *$ & $0.626 *$ \\
\hline & Sig. (2-tailed) & 0.084 & 0.101 & 0.029 & 0.009 & 0.003 & 0.002 & 0.029 \\
\hline \multirow[t]{2}{*}{$\mathrm{T}^{\circ} \mathrm{C}$} & Correlation coefficient & $0.798^{* *}$ & $0.739 * *$ & 0.414 & 0.313 & -0.0325 & 0.312 & 0.414 \\
\hline & Sig. (2-tailed) & 0.002 & 0.006 & 0.181 & 0.322 & 0.302 & 0.324 & 0.181 \\
\hline \multirow[t]{2}{*}{ HMF } & Correlation coefficient & & $0.972 * *$ & & & & & \\
\hline & Sig. (2-tailed) & & 0.000 & & & & & \\
\hline \multirow[t]{2}{*}{$\mathrm{C}$} & Correlation coefficient & & & & $0.919 * *$ & $-0.902 * *$ & $0.804^{* *}$ & $1.000 * *$ \\
\hline & Sig. (2-tailed) & & & . & 0.000 & 0.000 & 0.002 & \\
\hline \multirow[t]{2}{*}{$\mathbf{h}$} & Correlation coefficient & & & & & $-0.982 * *$ & $0.942 * *$ & $0.919 * *$ \\
\hline & Sig. (2-tailed) & & & & & 0.000 & 0.000 & 0.000 \\
\hline \multirow[t]{2}{*}{$L^{*}$} & Correlation coefficient & & & & & & $-0.951 * *$ & $-0.902 * *$ \\
\hline & Sig. (2-tailed) & & & & & & 0.000 & 0.000 \\
\hline \multirow[t]{2}{*}{$a^{*}$} & Correlation coefficient & & & & & & & $-0.804^{* *}$ \\
\hline & Sig. (2-tailed) & & & & & & & 0.002 \\
\hline
\end{tabular}

${ }^{* *}$ Correlation is significant at the 0.01 level (2-tailed); ${ }^{*}$ Correlation is significant at the 0.05 level (2-tailed).

Table 7. Kinetic parameters for 5-hydroxymethylfurfural (HMF) and 2-furaldehyde (2F) formation in MdL stored under different temperatures $\left(30,35,40^{\circ} \mathrm{C}\right)$.

\begin{tabular}{|c|c|c|c|c|c|c|c|}
\hline \multicolumn{4}{|c|}{ HMF } & \multicolumn{4}{|c|}{$2 F$} \\
\hline $\begin{array}{c}\mathrm{T} \\
\left({ }^{\circ} \mathrm{C}\right)\end{array}$ & $\begin{array}{c}k \\
\text { days }^{-1}\end{array}$ & $R^{2}$ & $\begin{array}{c}\mathrm{Ea} \\
\mathrm{kJ} \mathrm{mol}^{-1} \\
\left(\mathrm{kcal} \mathrm{mol}^{-1}\right)\end{array}$ & $\begin{array}{c}\mathrm{T} \\
\left({ }^{\circ} \mathrm{C}\right)\end{array}$ & $\begin{array}{c}k \\
\text { days }^{-1}\end{array}$ & $R^{2}$ & $\begin{array}{c}\mathrm{Ea} \\
\mathrm{kJ} \mathrm{mol}^{-1} \\
\left(\mathrm{kcal} \mathrm{mol}^{-1}\right)\end{array}$ \\
\hline $30^{\circ} \mathrm{C}$ & 0.0144 & 0.9538 & & $30^{\circ} \mathrm{C}$ & 0.0038 & 0.6275 & \\
\hline $35^{\circ} \mathrm{C}$ & 0.0150 & 0.9448 & $11.7(2.8)$ & $35^{\circ} \mathrm{C}$ & 0.0070 & 0.9010 & $66.4(15.9)$ \\
\hline $40^{\circ} \mathrm{C}$ & 0.0167 & 0.9872 & & $40^{\circ} \mathrm{C}$ & 0.0088 & 0.9488 & \\
\hline
\end{tabular}

In recent years, much research has been focused on the influence of light exposure to wine composition, in particular, on white wine, but also on red wine $[41,43]$. The phenomenon of light-induced off-flavors in wine, called "light-struck taste" (LST) [40,46], together with bottle color, storage condition and temperature effect were studied to improve the quality maintenance of wine during its storage [40,43,47-49]. To the best of our knowledge, no one has studied light interactions and bottle's color, or the temperature's effect on HMF and 2F, during a prolonged storage of 90 and 180 days, respectively.

\section{Conclusions}

The study was conducted in order to assess the changes in some quality attributes of MdL wine as a function of clear-colored glass bottles, lighting and temperature. Overall, the quality parameters of MdL wine were not significantly altered with the exposure to different lighting conditions and under different storage conditions, however, some changes in the color parameters occurred in every tested condition. In contrast with common beliefs, the bottle color did not play a significant role in the quality maintenance of this sweet wine. The significant increase in the levels of HMF and $2 \mathrm{~F}$ was mainly dependent on the 
intensity of lighting and on the storage temperature, as confirmed by the activation energy, without noticeable effects of the bottle color. Results suggest that retailers have a higher responsibility in the product quality maintenance compared to the company's choices of bottle color, which, in the specific case of MdL wine, can be merely driven by marketing consideration. Finally, HMF and $2 \mathrm{~F}$ levels can be considered as global quality indicators for MdL wine during storage, offering a tool for detecting unsuitable storage conditions.

In conclusion, the quality maintenance of wine can be achieved by controlling environmental factors, such as light exposure and temperature, during its storage guaranteeing profits for wine producers and satisfaction for consumers.

Author Contributions: Conceptualization: G.M. F.L. B.F.; Formal analysis: E.A.; V.R.; F.L.; Writingoriginal draft: V.R.; F.L.; Writing-review and editing: E.A.; V.R.; F.L.; B.F; G.M. All authors have read and agreed to the published version of the manuscript.

Funding: The research was supported by the Project "Valutazione della sostenibilità dei sistemi agroalimentari locali e selezione di markers molecolari e biologici nella gestione della qualità di prodotti agroalimentari" funded by the University of Catania (Italy).

Acknowledgments: The authors thank Carlo Nicolosi Asmundo and Marco Nicolosi for kindly supplying Malvasia delle Lipari DOC wine.

Conflicts of Interest: The authors declare no conflict of interest.

\section{References}

1. Del Nobile, M.; Ambrosino, M.; Sacchi, R.; Masi, P. Design of Plastic Bottles for Packaging of Virgin Olive Oil. J. Food Sci. 2003, 68, 170-175. [CrossRef]

2. Piergiovanni, L.; Limbo, S. The protective effect of film metallization against oxidative deterioration and discoloration of sensitive foods. Packag. Technol. Sci. 2004, 17, 155-164. [CrossRef]

3. Licciardello, F.; Del Nobile, M.A.; Spagna, G.; Muratore, G. Scalping of ethyloctanoate and linalool from a model wine into plastic films. LWT 2009, 42, 1065-1069. [CrossRef]

4. Aldave, L.; Almy, J.; Cabezudo, M.D.; Caceres, I.; Gonzales-Raurich, M.; Salvador, M.D. The shelf life of young white wines. In Shelf Life Studies of Foods and Beverages; Charalambous, G., Ed.; Elsevier: London, UK, 1993; pp. 923-943.

5. Sanova-Savova, S.; Dimov, S.; Ribarova, F. Anthocyanins and Color Variables of Bulgarian Aged Red Wines. J. Food Compos. Anal. 2002, 15, 647-654. [CrossRef]

6. Singleton, V.L. Oxygen with phenols and related reactions in musts, wines and model systems: Observations and practical implications. Am. J. Enol. Vitic. 1987, 38, 69-76.

7. Cheynier, V.; Rigaud, J.; Souquet, J.M.; Barillére, J.M.; Moutounet, M. Effect of pomace contact and hyperoxidation on the phenolic composition and quality of Grenache and Chardonnay wines. Am. J. Enol. Vitic. 1989, 40, 36-42.

8. Cheynier, V.; Rigaud, J.; Souquet, J.M.; Barillére, J.M.; Moutounet, M. Must browning in relation to the behaviour of phenolic compounds during oxidation. Am. J. Enol. Vitic. 1990, 41, 346-349.

9. Sims, C.; Morris, J. The effect of $\mathrm{pH}$, sulfur dioxide, storage time and temperature on the color and stability of red muscadine grape wine. Am. J. Enol. Vitic. 1984, 35, 35-39.

10. Gomez-Plaza, E.; Minano, A.; Lopez-Roca, J.M. Comparison of chromatic properties, stability and antioxidant capacity of anthocyanin-based aqueous extracts from grape pomace obtained from different vinification methods. Food Chem. 2006, 97, 87-94. [CrossRef]

11. Marquez, A.; Serratosa, M.P.; Merida, J. Influence of bottle storage time on colour, phenolic composition and sensory properties of sweet red wines. Food Chem. 2014, 146, 507-514. [CrossRef] [PubMed]

12. Recamales, A.F.; Sarago, A.; Gonzalez-Miret, M.L.; Hernanz, D. The effect of time and storage conditions and colour of white wine. Food Res. Int. 2006, 39, 220-229. [CrossRef]

13. Kallithraka, S.; Salacha, M.I.; Tzourou, I. Changes in phenolic composition and antioxidant activity of white wine during bottle storage: Accelerated browning test versus bottle storage. Food Chem. 2009, 113, 500-505. [CrossRef]

14. Selli, S.; Canbas, A.; Unal, U. Effect of bottle colour and storage conditions on browning of orange wine. Nahrung/Food 2002, 46, 64-67. [CrossRef]

15. Benitez, P.; Castro, R.; Garcia Barroso, C. Changes in the Polyphenolic and Volatile Contents of "Fino" Sherry Wine Exposed to Ultraviolet and Visible Radiation during Storage. J. Agric. Food Chem. 2003, 51, 6482-6487. [CrossRef]

16. Dias, D.A.; Smith, T.A.; Ghiggino, K.P.; Scollary, G.R. The role of light, temperature and wine bottle colour on pigment enhancement in white wine. Food Chem. 2012, 135, 2934-2941. [CrossRef]

17. Maury, C.; Clark, A.C.; Scollary, G.R. Determination of the impact of bottle colour and phenolic concentration on pigment development in white wine stored under external conditions. Anal. Chim. Acta 2010, 660, 81-86. [CrossRef] 
18. Revi, M.; Badeka, A.; Kontakos, S.; Kontominas, M.G. Effect of packaging material on enological parameters and volatile compounds of dry white wine. Food Chem. 2014, 152, 331-339. [CrossRef] [PubMed]

19. Clark, A.C.; Dias, D.A.; Smith, T.A.; Ghiggino, K.P.; Scollary, G.R. Iron (III) Tartrate as a potential precursor of light-induced oxidative degradation of white wine: Studies in a model wine system. J. Agric. Food Chem. 2011, 59, 3575-3581. [CrossRef]

20. D. P. R. 20.09. 1973. Assignment of the Denomination of Controlled Origin of "Malvasia delle Lipari" Wine Official Gazzette of the Republic of Italy $n^{\circ} 28,(30.01 .1974)$. Available online: http:/ / catalogoviti.politicheagricole.it/scheda_denom.php?t=dsc\&q=2175 (accessed on 22 January 2018).

21. Muratore, G.; Nicolosi Asmundo, C.; Lanza, C.M.; Caggia, C.; Licciardello, F.; Restuccia, C. Influence of Saccharomyces uvarum on volatile acidity, aromatic and sensory profile of Malvasia delle Lipari wine. Food Technol. Biotech. 2007, 45, 101-106.

22. Belitz, H.B.; Grosch, W.; Schieberle, P. Food Chemistry, 3rd ed.; Springer: Berlin/Heidelberg, Germany, 2004 ; pp. $258-282$.

23. Rada-Mendoza, M.; Olano, A.; Villamiel, M. Determination of hydroxymethylfurfural in commercial jams and in fruit-based infant foods. Food Chem. 2002, 79, 513-516. [CrossRef]

24. Rada-Mendoza, M.; Sanz, M.L.; Olano, A.; Villamiel, M. Study on nonenzymatic browning in cookies, crackers and breakfast cereals by maltulose and furosine determination. Food Chem. 2004, 85, 605-609. [CrossRef]

25. Arena, E.; Fallico, B.; Maccarone, E. Evaluation of antioxidant capacity of blood orange juices as influenced by constituents, concentration process and storage. Food Chem. 2001, 74, 423-427. [CrossRef]

26. Arena, E.; Muccilli, S.; Mazzaglia, A.; Giannone, V.; Brighina, S.; Rapisarda, P.; Fallico, B.; Allegra, M.; Spina, A. Development of Durum Wheat Breads Low in Sodium Using a Natural Low-Sodium Sea Salt. Foods 2020, 9, 752. [CrossRef] [PubMed]

27. Zappalà, M.; Fallico, B.; Arena, E.; Verzera, A. Methods for the determination of HMF in honey: A comparison. Food Control 2005, 16, 273-277. [CrossRef]

28. Spina, A.; Brighina, S.; Muccilli, S.; Mazzaglia, A.; Rapisarda, P.; Fallico, B.; Arena, E. Partial Replacement of NaCl in Bread from Durum Wheat (Triticum turgidum L. subsp. durum Desf.) with $\mathrm{KCl}$ and Yeast Extract: Evaluation of Quality Parameters During Long Storage. Food Bioprocess Technol. 2015, 8, 1089-1101. [CrossRef]

29. Spina, A.; Brighina, S.; Muccilli, S.; Mazzaglia, A.; Fabroni, S.; Fallico, B.; Rapisarda, P.; Arena, E. Wholegrain Durum Wheat Bread Fortified With Citrus Fibers: Evaluation of Quality Parameters During Long Storage. Front. Nutr. 2019, 6, 13. [CrossRef]

30. Pereira, V.; Albuquerque, F.M.; Ferreira, A.C.; Cacho, J.; Marques, J.C. Evolution of 5-hydroxymethylfurfural (HMF) and furfural (F) in fortified wines submitted to overheating conditions. Food Res. Int. 2011, 44, 71-76. [CrossRef]

31. Cutzach, I.; Chatonnet, P.; Henry, R.; Pons, M.; Dubourdieu, D. Etude de l'arome des vins doux naturels non muscatés. 2eme Partie: Dosage de certains composés volatils intervenant dans l'arome des vins doux naturels au cours de leur vieillissement. $J$. Int. Scie de la Vigne et du Vin 1998, 34, 211-221. (In French)

32. Lee, Y.C.; Shlyankevich, M.; Jeong, H.K.; Douglas, J.S.; Surh, Y.J. Bioactivation of 5-hydroxymethyl-2-furaldehyde to an electrophilic and mutagenic allylicsulfuric acid ester. Biochem. Biophys. Res. Commun. 1995, 209, 996-1002. [CrossRef]

33. Surh, Y.J.; Liem, A.; Miller, J.A.; Tannenbaum, S.R. 5-Sulfooxymethylfurfural as a possible ultimate mutagenic and carcinogenic metabolite of the Maillard reaction product, 5-hydroxymethylfurfural. Carcinogenesis 1994, 15, 2375-2377. [CrossRef] [PubMed]

34. Durling, L.J.K.; Busk, L.; Hellman, B.E. Evaluation of the DNA damaging effect of the heat-induced food toxicant 5hydroxymethylfurfural (HMF) in various cell lines with different activities of sulfotransferases. Food Chem. Toxicol. 2009, 47, 880-884. [CrossRef]

35. Li, Y.-H.; Lu, X.Y. Investigation on the origin of 5-HMF in Shengmaiyin decoction by RP-HPLC method. J. Zhejiang Univ. Sci. B 2005, 6, 1015-1021. [CrossRef] [PubMed]

36. Rizzo, V.; Torri, L.; Licciardello, F.; Piergiovanni, L.; Muratore, G. Quality changes of extra virgin olive oil packaged in coloured PET bottles stored under different lighting conditions. Packag. Technol. Sci. 2014, 27, 437-448. [CrossRef]

37. OIV International Organization of Vine and Wine. Compendium of International Methods of Analysis of Wines and Musts (2 volUMES). Available online: https://www.oiv.int/en/technical-standards-and-documents/methods-of-analysis/compendiumof-international-methods-of-analysis-of-wines-and-musts-2-vol (accessed on 22 January 2018).

38. Di Stefano, R.; Cravero, M.C.; Gentilini, N. Metodo per lo studio dei polifenoli nei vini. L'Enotecnico 1989, Maggio, 83-89.

39. Hopfer, H.; Ebeler, S.E.; Heymann, H. The combined effects of storage temperature and packaging type on the sensory and chemical properties of Chardonnay. J. Agric. Food Chem. 2012, 60, 10743-10754. [CrossRef] [PubMed]

40. Arapitsas, P.; Dalledonne, S.; Scholz, M.; Catapano, A.; Carlina, S.; Mattivi, F. White wine light-strike fault: A comparison between flint and green glass bottles under the typical supermarket conditions. Food Packag. Shelf Life 2020, 24, 100492. [CrossRef]

41. Díaz, I.; Castro, R.I.; Ubeda, C.; Loyola, R.; Laurie, V.F. Combined effects of sulfur dioxide, glutathione and light exposure on the conservation of bottled Sauvignon blanc. Food Chem. 2021, 356, 129689. [CrossRef] [PubMed]

42. Refsgaard, H.H.; Brockhoff, P.B.; Poll, L.; Olsen, C.E.; Rasmussen, M.; Skibsted, L.H. Light-induced sensory and chemical changes in aquavit. LWT 1995, 28, 425-435. [CrossRef]

43. Guerrini, L.; Pantani, O.; Politi, S.; Angeloni, G.; Masella, P.; Calamai, L.; Parenti, A. Does bottle color protect red wine from photo-oxidation? Packag. Technol. Sci. 2019, 32, 259-265. [CrossRef]

44. Muratore, G.; Licciardello, F.; Restuccia, C.; Puglisi, M.L.; Giudici, P. Role of Different Factors Affecting the Formation of 5-Hydroxymethyl-2-furancarboxaldehyde in Heated Grape Must. J. Agric. Food Chem. 2006, 54, 860-863. [CrossRef] [PubMed]

45. Cutzach, I.; Chatonnet, P.; Dubourdieu, D. Study of the formation mechanisms of some volatile compounds during the aging of sweet fortified wines. J. Agric. Food Chem. 1999, 47, 2837-2846. [CrossRef] [PubMed] 
46. Fracassetti, D.; Di Canito, A.; Bodon, R.; Messina, N.; Vigentini, I.; Foschino, R.; Tirelli, A. Light-struck taste in white wine: Reaction mechanisms, preventive strategies and future perspectives to preserve wine quality. Trends Food Sci. Technol. 2021, 112, 547-558. [CrossRef]

47. Benucci, I. Impact of post-bottling storage conditions on colour and sensory profile of a rosé sparkling wine. LWT 2019, 118, 108732. [CrossRef]

48. Jung, R.; Kumar, K.; Patz, C.; Rauhut, D.; Tarasov, A.; Schüßler, C. Influence of transport temperature profiles on wine quality. Food Packag. Shelf Life 2021, 29, 100706. [CrossRef]

49. Lan, H.; Li, S.; Yang, J.; Li, J.; Yuan, C.; Guo, A. Effects of light exposure on chemical and sensory properties of storing Meili Rose wine in colored bottles. Food Chem. 2021, 345, 128854. [CrossRef] [PubMed] 